\title{
Indonesian Muslim killings: revisiting the forgotten Talang Sari tragedy (1989) and its impact in post authoritarian regime
}

\author{
Wahyudi Akmaliah \\ Research Centre for Society and Culture \\ Indonesian Institute of Science (PMB-LIPI) \\ E-mail:wahyudiakmaliah@gmail.com \\ DOI: 10.18326/ijims.v6i1.1-34
}

\begin{abstract}
Although the Talang Sari tragedy as a part of the representation of Indonesian Muslim oppression during the authoritarian regime, it is relatively lesser known for Indonesian public. The avoidance of the most Indonesian Muslim who did not support it is one of those facts. Indeed, they did a less attention to talk and to articulate the case to the public. This paper intends to revisit the case of the Talang Sari as one of the unsolved human rights violation during the authoritarian regime. It is not only exploring the case and also examining the context of violence, but also tracing dynamic of the case during and post of authoritarian regime by the emergence of Islah agreement as cultural impunity to forget the past for many victims. The questions deals with in this paper are following: what kind of conditions that made the Talang Sari was happening in East Lampung in 1989, South Sumatra during the Suharto presidency? How did the Suharto regime control the discourse of the tragedy in Indonesian public that eventually encourage most Indonesian Muslim did not ac-
\end{abstract}


tively respond the killings? Although the reformasi era gives an opportunity break silences by asking justice to the current Indonesian government on human rights violation, why those cases, especially the Talang Sari, are unsolved? This paper divided into three parts to answering the questions. Firstly, it is to understand the case of Talang Sari by discussing the context of the New Order's policy on Indonesian Muslim and its political ideology. Secondly, it is to read deeply mass media in making discourse on the case as one of the triggers for most Indonesian Muslim did not respond it. Thirdly, it is to analyze the Islah agreement (reconciliation in Islamic term) as the primary factor that contributed why cultural impunity has seemingly embedded to bring justice to the victims of violence generally in the post of Suharto regime.

Meskipun Peristiwa Talang Sari sebagai bagian dari representasi penindasan masyarakat Muslim Indonesia selama rejim otoriter berkuasa, peristiwa itu jarang diketahui oleh publik Indonesia. Pengabaian kebanyakan Muslim Indonesia yang tidak mendukung upaya penyelesaian kasus tersebut adalah salah satu buktinya. Bahkan, mereka tidak membicarakan dan mengangkat kasus Talang Sari di ruang publik. Artikel ini bermaksud melihat kembali peristiwa Talang Sari sebagai salah satu kasus pelanggaran yang belum diselesaikan. Selain mengeksplorasi kasus, menjelaskan konteks kekerasan, artikel ini juga menelusuri dinamika kasus tersebut sebelum dan pasca rejim Orde Baru, khususnya seiring dengan kemunculan Islah sebagai Impunitas Kultural untuk melupakan masa lalu oleh sebagaian korban. Pertanyaannya yang diajukan dalam artikel ini adalah: kondisi-kondisi semacam apa yang membuat kasus Talang Sari terjadi di Lampung Timur pada tahun 1989, Sumatera Selatan saat presiden Suharto berkuasa? Bagaimana rejim Suharto mengontrol wacana peristiwa tersebut yang membuat kebanyakan masyarakat Islam Indonesia tidak menanggapi peristiwa tersebut? Meskipun pasca rejim Orde Baru memberikan kesempatan untuk menyelesaikan kasus tersebut dengan mendesak untuk mengajukan keadilan kepada pemerintah Indonesia, mengapa peristiwa Talang Sari tidak atau belum diselesaikan hingga sekarang?. Untuk menjawab pertanyaan-pertanyaan tersebut, saya membagi penjelasan ini kepada tiga bagian. Pertama, memahami kasus Talang Sari dengan mendiskusikan konteks kebijakan rejim Orde Baru dalam menghadapi umat Islam dan ideologi politiknya. Kedua, membaca lebih dalam media cetak dalam membuat wacana peristiwa tersebut 
melalui liputan yang dibuat. Asumsi ini diajukan karena liputan media tersebut menjadi salah satu penyebab mengapa kebanyakan umat Islam tidak merespon peristiwa tersebut. Ketiga, menganalisis persetujuan Islah, rekonsiliasi dalam perspektif Islam sebagai faktor utama yang memberikan kontribusi terhadap impunitas kultural untuk membawa keadilan ke jalan yang lebih sulit kepada korban secara umum pasca rejim Suharto.

Keywords: Talang Sari; Victims; Lampung; Islah; Islam; Human rights abuses

\section{Introduction}

His name is Azwar Kaili. He was born in 1942 in Painan, Padang, and South Sumatra. Due to local politic tension in his hometown, at the 18 years old he migrated to follow his uncle, Sahadi, in Tanjung Karang, in the residence of South Lampung in 1959. He met with his wife, and then they married on March 13, 1973. Working as both farmer and local trader with many businesses especially anything that related to agriculture, they steeply became a wealthy people in Sidorejo, East Lampung. However, a call letter on 6 February 1989 at 08.00 a.m. which had been sent to him for coming in the district of Jabung, had changed their life dramatically. He and his wife, as well as the two of their children, were arrested separately in the different prison. They thought as one of the members of Talang Sari for the two reasons. Firstly, it was due to his the biggest boy who was taking his high school in Islamic boarding school in Talang Sari under Warsidi's teaching. Secondly, it is because of his kindness to Zamzuri as a close neighbor where he often gave a room to sleep for Zamzuri's guests whose coming from Jakarta. Meanwhile, Zamzuri himself was the wealthy farmer who was interested in Warsidi's Islamic teaching. After releasing from the prison, their house was burned, and the valuable things they had were seized. Indeed, while he tried to advocate himself to the office of local police by sending a protest letter, he then prisoned for one month. This sadness did not stop here. For many years, he and his family 
must live under stigma as Mujahidin people (orang-orang Mujahidin), the insurgent group who fight against the Indonesian government. This condition could not make them freely as an Indonesian citizen to do anything, especially establishing social interaction with their neighbors and supporting their economy by being a trader as before it. ${ }^{1}$

The story above describes an impact of the tragedy for Indonesian Muslim that has changed their life during the Suharto regime presidency. Although the event of Talang Sari in Lampung (1989), South Sumatra, as one of the two events representing Indonesian Muslim's oppression during the New Order, it is relatively lesser known for Indonesian public. It could be seen by the avoidance of the most Indonesian Muslim who did not support the Talang Sari actively. Indeed, they did a less attention to talk and to articulate the case in the public as well as only two human rights NGOs concerns to support it, mainly both KontraS and Komite Smalam. It is difference response in comparison with the case of Tanjung Priok. In my earlier writing, I noted that "there are two organizations that defend the case of Tanjung Priok, namely SONTAK (National Solidarity for the victims of Tanjung Priok tragedy) led by Syarifini Maloko as part of the victims and a student organization of KOMPAK (Student and Youth Committee for non-Violence led by Yayan Hendrayana”. In addition, before the two organizations built, as I asserted "there were two thousands of Indonesian Muslim attending Islamic gathering on September 12, 1998 in order to remember the tragedy of Tanjung Priok, including Islamic prominent from various backgrounds such as Yuzril Ihza mahendra (the Crescent Star Party), Said Aqil Siradj (Nahdatul Ulama), Jalaluddin Rahmat (Islamic scholar), and Munir Thalib (KontraS's activitist)". Though

\footnotetext{
${ }^{1}$ Wahyudi Akmaliah, Dari Penjara Ke Penjara: Narasi Personal Kehidupan Azwar Kaili, Korban Peristiwa Talang Sari, 1989, unpublished article, 2010, 1-5.

${ }^{2}$ Wahyudi Akmaliah, Menggadaikan Islah : Politisasi Islah di Kalangan Korban Priok (1984), 2009, 82.
} 
the Talang Sari is not a part of a social memory of most Indonesian nationally, it is one of the cases investigated by the National Commission on Human Right (Komnas HAM) where the result has been brought as a recommendation to the Attorney General (Kejaksaan Agung).

I intend to revisit the case of the Talang Sari as one of unsolved human rights violation during the authoritarian regime. It is not only exploring the case and also examining the context of violence, but also tracing dynamic of the case during and post of an authoritarian regime by the emergence of Islah agreement as cultural impunity to forget the past for many victims. The questions deal with in this article is following: what kind of conditions that made the Talang Sari was happening in East Lampung in 1989, South Sumatra during the Suharto presidency? How did the Suharto regime control the discourse of the tragedy in Indonesian public that eventually encourage most Indonesian Muslim did not actively respond the killings on it? Although, the reformasi era gives an opportunity break silences by asking justice to the current Indonesian government on human rights violation, why those cases, especially the Talang Sari, are unsolved?

\section{Islam and the Talang Sari tragedy in New Order context}

\section{How did the Suharto Presidency dealt with Islam?}

Although Islam is majority religion in Indonesia that have been practiced by around of $80 \%$ from all of the Indonesian population, a relationship between government and Islamic society (including community, party, as well as ideology) always went up and down. Compared with the Sukarno presidency, this dynamic relation could be seen clearly during the Suharto administration for 32 years in his power. It indirectly has changed the path of Islam in post of the authoritarian regime to define an identity of Indonesian Muslims and to imagine what the face of Islam 
within the Indonesian nation is and, on the other hand, as part of the global context of ummah. Instead of thinking the New Order as an antiIslam during his power, they had different policies that often related to the context of authority they made as well as allies they built. Given this explanation, there are three periods of relation how the Suharto presidency deal with Islam in issuing a different policy.

In the first period, it is to place most Indonesian Muslims as a partner to kill those people who involved and related with the Indonesian Communist Party (PKI) and it is under bows as well as labeling people as PKI during 1965-1966 (1965-1970s). At least, there are two of mass Muslims organization that are suspected had involved in this killing, namely Nahdatul Ulama (NU) with its organization apparatus, Banser (Barisan Ansor Serba Guna) and the rest of Masyumi's people that spread into the small Muslim groups. Both a 'conflict ideology' that had ever emerged a 'religious tension' and labeling the PKI as the biggest evil through a fiction story are the two triggers as a seemingly reasonable choice to encourage them as a killer. As well known, during the Sukarno presidency, the PKI was one of the biggest parties, supported by Sukarno to do land reform. Both the PKI and the mass Muslims organizations, represented by the party of NU and Masyumi, historically had the different ideology that caused conflict. Therefore, these historical backgrounds and the fiction stories of the PKI were as the firm legitimacy for the two organizations to kill them. Although, in the level of grassroots, there were some plans systematically that had been provided the piece of the list of the name as a target for killing. Here, both Berita Yudha and Angkatan Bersenjata as the military's non-communist national newspaper were another useful material as the primary factor to exaggerate and escalate for the killings. ${ }^{3}$

\footnotetext{
1999.

${ }^{3}$ Saskia Wieringa, Penghancuran Gerakan Perempuan di Indonesia. Jakarta: Garba Budaya,
} 
In the second period, it is to make Indonesian Muslims as a threat of the New Order's enemy after PKI (1970-1990s). Despite Muslims from various religious groups as butchers to kill the PKI and its sympathizers, it does not mean they also became 'a close friend.' For the New Order regime, Islam was the threat as same as the PKI that could challenge their policies. They became anti-Islam after strengthening their both infrastructure and structure in the level of government through the military backing as well as creating a political system to be centralized by curtailing political freedom only the three parties in Indonesian political system (PPP, PDI-P, and Golkar). Also, they also controlled all political parties and all mass organizations by forcing them to adopt the state of ideology as the sole of their ideological basis. Some of those indications were they did not allow the rise of political Islam and Islamist parties by not giving a permit to re-establish and revived Masyumi party which had been banned by the Sukarno presidency in 1959. They also prohibited Muslim girl from wearing the veil in the public schools and did not allow prostitution districts (lokalisasi) and gambling. Also, they attempted to recognize aliran kepercayaan (indigenous mysticism) as a legal religion in Indonesia and to practice the family planning (Keluarga Berencana/KB). ${ }^{4}$ Those policies undoubtedly had attracted the mass Muslims organizations' respond to resist them. Both the Tanjung Priok tragedy on September 14, 1984, and the Talang Sari tragedy on February 7, 1989, then is the New Order's atrocity symbol of Islam. ${ }^{5}$

\footnotetext{
${ }^{4}$ Bahtiar Effendi, Islam dan Negara:Transformasi Pemikiran dan Praktik Politik Islam di Indonesia. Jakarta: Paramadina, 1998, 50. Najib Burhani, "The Reformasi '98 and the Arab Spring: A Comparative Study of Popular Uprisings in Indonesia and Tunisia”, Asian Politics \& Policy, Volume 6, Number 2, (2014), 202.

${ }^{5}$ Wahyudi Akmaliah, "Ingatan yang Diabaikan: Islam, Kekerasan Masa Lalu, dan Aspirasi Politik Pasca Orde Baru”, Pusat Penelitian Politik LIPI, 6 Juni 2014, http:// www.politik.lipi.go.id/kolom/kolom-2/politik-nasional/996-ingatan-yang-diabaikan-islamkekerasan-masa-lalu-dan-aspirasi-politik-pasca-orde-baru.
} 
In the third period, it is pretended to be Islamic regime (1990-1998). Regarding the military's disappointed partly backing to the Suharto presidency due his family member's corruption that asked for a greater share of the pie, he then thought to approach Islam as part of government system to make his power more stable. It had definitely changed the serious condition of most Indonesian Muslims from being 'enemy' to be 'friend' as previously, from a peripheral into a central position in the government. One of Suharto's ways firstly for being a pious Muslim was he went to pilgrimage to Mecca with his families and went back to Jakarta by adding "Muhammad" as his first name that became Muhammad Suharto. Besides, his first daughter, Tutut started to wear a veil (kerudung) while attending the social activity in the public sphere. It was then followed by other programs that supported Islamic religion such as both supporting the establishment of the first of Islamic Bank Indonesia, Muamalat, and endorsing the creation of the Association of Indonesian Muslim Intellectual (Ikatan Cendikiawan Muslim Indonesia/ICMI). Capturing an image of the Suharto presidency that supported Islam, Robert Heffner ${ }^{6}$ as cited by Burhani ${ }^{7}$ has described it correctly as a man who "shattered in one fell swoop one of the most enduring stereotypes of New Order politics. Here, after all, was a man long regarded as a staunch defender of Javanese mysticism and Pancasila pluralism giving his blessing to an elite Muslim organization openly dedicated to the Islamization of Indonesian society”.

\section{The Talang Sari tragedy}

Putting the place of the Talang Sari tragedy from the above narrative, I can explain that it is the second moment while the Suharto showed as

\footnotetext{
${ }^{6}$ Robert Heffner, Civil Islam: Muslims and Democratization in Indonesia. Princeton, NJ: Princeton University Press, 2000, 128.

${ }^{7}$ Najib Burhani, "The Reformasi '98 and the Arab Spring..., 204.
} 
anti-Islam. To explain it in detail, I describe it below more locally by exploring the context of an Islamic group in Talang Sari that connects with Islamic group from both Solo and Jakarta. As explained, it is not only the sole of violence that had impacted to Indonesian Muslim committed by the military; there was previously the Tanjung Priok tragedy happened in South Jakarta in 1984. However, comparing to the Tanjung Priok, the Talang Sari was infamous. Instead of happening at the national level and it was quite close from Jakarta as the capital city of Indonesia, it occurred in the countryside, especially in the former village of Cihideung, Talang Sari III, East Lampung (before it was part of South Lampung), South Sumatera. The location was far from the city of Bandar Lampung as the center of local government and business traders. Although both were a different place, mainly between the capital city and town that tended to influence Indonesian's perception, they had similarities while the killings happened due to their resistance to fighting against the Suharto regime's policy that often suppressed and marginalized Islam.

There were series of the events that had encouraged the killings, mainly from December 1988 -January 1989. ${ }^{8}$ In these years, there were numbers of people by bringing their families who migrated from Java's Island (Solo, Bandung, and Jakarta) to the village of Rajabasa in South Lampung (currently is East Lampung). The main reason they migrated was as part of their strategy to hide and to avoid from the operation target during 1985196 which acted by Harsudiono Hartas as the General Major of the Diponegoro Territorial Military Commander. It was regarding their activity as the Islamist, joining the Usrah Movement, led by Abdullah Sungkar in Solo, Central Java. As known, the Suharto regime at the end of the year 1985 destroyed the Abdullah Sungkar's Usrah movement

\footnotetext{
${ }^{8}$ KontraS, Peristiwa Talang Sari 1989: Sebuah Kisah Tragis Yang Hendak Dilupakan, Jakarta: Kontras, 2006.
} 
due to their resistance to refuse the ideology of Pancasila as the sole basis through the social organization act of UU No. 3 and 8, in 1985. Meanwhile, in the South Lampung, there were already both Warsidi and his followers made Islamic gathering become a pious Muslim. The presence of Fadillah as the member of Usroh Movement by bringing his family living in the village of Karang Asem, district of Labuhan Maringgai, South Lampung, joining a house with Darhari as his old friend while they were in central Java, then made him incidentally met Warsidi. Through these series of meetings, Warsidi, and his followers as well as Fadillah's family steeply wanted to establish Islamic village by planning to build Pondok Pesantren (Islamic boarding school). They then moved to the village of Umbul Cihideung especially in the orchard of Talang Sari III, District of Way Jepara, located in The East (before it was South) Lampung to realize it after getting $1 \frac{1 / 2}{2}$ hectare of the land freely from Jayus, one of Warsidi's followers. ${ }^{9}$

Though the profession of Warsidi as both religious teacher and tenant farmer, the Islamic gathering he built was quite successful. Both his charisma and kindness as the symbol of capital for being a pious Muslim had attracted some local people to bring his children, most of them were youth (10-19 age), to join his Islamic activities. Indeed, Zamzuri, one of his followers who were coming from his product of social economic allowed his request to stay Abdullah, one of the Usrah movement members in his house as an Islamic teacher in the village of Sidorejo. Through Abdullah's teaching in tandem with parents' dream to educate their boys and daughters in the line of Islamic religion, many youths of the village had joint his Islamic gathering. Although his profession as Islamic teacher

${ }^{9}$ Abdul Syukur, Gerakan Usroh di Indonesia: Kasus Peristiwa Lampung 1989, Tesis, Program Studi Ilmu Sejarah, Bidang Ilmu Pengetahuan Budaya, Program Pascasarjana Sastra, Universitas Indonesia, 2001, 131-133. Abdul Syukur, Gerakan Usroh Di Indonesia: Peristiwa Lampung 1989. Yogyakarta: Ombak, 2003, 108-113. 
who taught them in the evening as well as their excellent guide how to become a pious Muslim by practicing their daily life by Islamic principle, Abdullah also became Zamzuri's assistance as a farmer planting rice plant. Thereby, there were two Islamic gatherings relating each other; the first was in Sidorejo led by Abdullah especially for Islamic youths and the second was in Talang Sari III led by Warsidi as well as some of the Islamists of Usroh movement coming from the Java Island.

The seed of conflict steeply started while Sukidi, the head of the Talang Sari village, informed to Zulkifli, the head of the Way Jepara district, on both Islamic gathering activities and new comers from out of the village without any permits on 20 January 1989. As Zulkifli's representation, Amir Puspa Muga, the head of the village Rajabasa Lama then sent an invitation letter for Warsidi. The letter content that had been forwarding to both the commander of the army administrative unit and the head of the district of police in Way Jepara was asking him to come and to meet Zulkifli in his office (Kontras, 2006). As an ordinary people who never dealt with the government's apparatus, Warsidi was very nervous and panic. He did not know what he had to do dealing with the letter. He then asked his followers, Sofwan went to Jakarta to meet with Nurhidayat, one of the Usroh movement's members. At that day, Nurhidayat with the other members, mainly Sudarsono and Nur iswan, went to Talang Sari. Through the serious meeting, Warsidi, his followers, and some other members of Usroh movement discussed the letter and how they responded it. The point of discussion was definitely proposing the two options; either he had to come or not. Followers said that he should respond it by coming to the district office, and they would have accompanied him to explain some reasons why they came to Talang Sari. The rest suggested him to refuse it because it was only a trick to arrest him. He finally chose the second option for not going to the office, but 
he just sent the letter that contained the objection and explained some reasons provocatively why he refused to come. On the contrary, he invited Zulkifli as the district of Way Jepara to come to his place, seeing what the real condition in Talang Sari was. ${ }^{10}$

"......we are really busy with our teaching of Islamic gathering in any places. Because of this, we cannot come to your office. As Muslim, we have had the highest commitment to God's will and the prophet of Muhammad's teaching. In a hadith was said that the best of Umara (a kind of leader in government official) are those who come to Ulama (Islamic scholars) and the worst of Ulama are those who are coming to Umara. Therefore, we expect that Bapak (Mr) kindly can come to our place to know the real condition....." (Syukur, 2003: 124).

Warsidi sent the letter on January 21, 1989. Surprisingly, both Zulkifli and his staffs had responded it immediately by coming to Talang Sari at that day. This quick reply evidently made him and his members surprised. Because mostly the backgrounds of Islamic gathering members were a farmer, many of them were going to the field while Zulkifli and his staffs arrived at the Talang Sari. The rest of them who stayed in Talang Sari then just welcome them in a simple way. Of course, their arrival was a good time for Warsidi to explain the presence of Islamic boarding school and his plan to establish Islamic village. Instead of listening what Warsidi wanted to say about the real condition, Zulkifli suddenly overlooked him in the meeting by saying the statement that insulted him. ${ }^{11}$ The day after the meeting, especially in the night of January 22, 1989, some local apparatuses came into the village of Talang Sari, while the two of them, using guns, had entered the small mosque of Al-Muhajirin without taking off their shoes. They barked at some of the members who were sleeping and

\footnotetext{
${ }^{10}$ Abdul Syukur, Gerakan Usroh di Indonesia..., 135.

${ }^{11}$ Abdul Syukur, Gerakan Usroh di Indonesia...., 136. Abdul Syukur, Gerakan Usroh Di Indonesia:..., 125
} 
laying down, "this lesson of community was wrong, it's resisting the government, and this village will be destroyed". Indeed, they incidentally pointed a gun directly to the members, mostly were youths. All the members of the Mosque did not respond the military's provocation until they finally left it. ${ }^{12}$

The relation between the Warsidi's Islamic gathering and the local governments became worst since the meeting. The impact was Zulkifli Maliki wrote the letter negative report on the Warsidi as the closed of Islamic gathering that could be a threat to national stability to Soetiman as the infantry captain in the commander 041121 of the army administrative unit of Way Jepara on 27 January 1989. The letter then also signified the changing of the surveillance responsibility from Zulkifli to Soetiman. This surveillance under Soetiman could be seen by the charter explanation for the three heads of the village (Pakuan Aji, Labuhan Ratu, and Raja Basa) that were close to the village of Talang Sari to scrutinize Warsidi's Islamic gathering and its activities and they obligated to make a report if there was something dangerous. In addition, Soetiman also sent Warsidi the invitation letter for coming to the office of the Military Headquarters at ward level 041121 at Way Jepara. The condition undoubtedly made Warsidi and followers more worried. Instead of responding it, they again refused to come and then tightened for the night watch and created their guns from bamboo as a form of their self-defense in Talang Sari. ${ }^{13}$

Because of this situation, Soetiman reported his activities to the District Military Command 0411 of South Lampung which then handled by

${ }^{12}$ KontraS, Peristiwa Talang Sari 1989, 2006. Abdul Syukur, Gerakan Usroh di Indonesia: Kasus Peristiwa Lampung 1989, 2001,....137. Abdul Syukur, Gerakan Usroh Di Indonesia: Peristiwa Lampung 1989, 2003,...125.

${ }_{13}$ Abdul Syukur, Gerakan Usroh di Indonesia: Kasus Peristiwa Lampung 1989, 2001,....137138. Abdul Syukur, Gerakan Usroh Di Indonesia: Peristiwa Lampung 1989, 2003,...125-126. 
E.O Sinaga as the Lieutenant Commander of District Military 0411. They then had a meeting on 4 February 1989, while it has produced the call letter of Warsidi for coming to meet them. Again, he refused it. His rejection then provoked the district military command of Metro to catch the six youths of the Islamic gathering while they became the night watcher on February 5, 1989. Instead of coming for calming down a tension and resolving conflict through such kind of peace agreement, they, represented by E.O Sinaga with his military troop from the Military Headquarters at the ward level of Way Jepara, provoked the members of Islamic gathering by giving them humiliation words that finally caused the conflict on February 6, 1989. Due the conflict, it caused the infantry captain of Soetiman finally died from a machete blow which acted by one of Warsidi's followers. The dead of Soetiman was a pretext for the Commander of 043/Garuda Hitam Resort Military Command in Lampung, Hendpriyono to 'attack' them in early morning, 04.00 am, in 7 February 1989, by both killing and burning them alive. (Syukur, 2001: 138-142; Syukur, 2003: 128132; Kontras, 2009: 4-5). Meanwhile, for those members and their families who related and even unrelated with the Warsidi's Islamic gathering as well as they were lost from the attack had been imprisoned for three months up to 4 years. Because of this atrocity, as the National Commission on Human Rights reports through their result investigation in 2008, there has been human rights violation that impacts the killing of 130 people, forced expulsion of 77 people, incarceration for 53, tortured by 46 individuals and ill-treatment or persecution for the amount of 229 people. ${ }^{14}$

\footnotetext{
${ }^{14}$ Kontras. Kronik Perjalanan Kasus Talang Sari. Jakarta: Kontras, 2009. Elsam, "Siaran Pers 23 Tahun Tragedi Talangsari: Ketika Negara Menolak Keadilan Korban”, 2012, http:/ /www.elsam.or.id/?id=1769\&lang=en\&act=view\&cat $=\mathrm{c} / 302$.
} 


\section{Dominating discourse of the Talang Sari tragedy in Indonesian public}

Through my observation, at least, eleven mass media were covering the Talang Sari, mainly Kompas, Pelita, Suara Karya, Merdeka, Berita Yudha, Angkatan Bersenjata, Tempo, Jakarta Post, Suara Pembaharuan, Poskota, and Antara. Many of them who published it showed that it was not only a small incident happened locally but also the significant issue nationally. It could be seen how it was to be either the headline or the first page that had been published one till seven days after the tragedy. However, to know how the way of mass media dominated by the state's information is by checking out the subject of an informant who became a citation source. Through the table below, we can consider which one of mass media predominantly following the authoritarian regime sources.

\section{Table. The Talang Sari in Mass Media}

\begin{tabular}{|c|c|c|c|c|}
\hline Mass Media & Title & Page & Date & Source \\
\hline $\begin{array}{l}\text { Angkatan } \\
\text { Bersenjata }\end{array}$ & $\begin{array}{l}\text { Lampung Regional Police } \\
\text { cracked down hordes of Security } \\
\text { Disturbance Movement (Polwil } \\
\text { Lampung Tumpas Gerombolan } \\
\text { Pengacau Keamanan di Talang } \\
\text { Sari) }\end{array}$ & 1 & $\begin{array}{l}10 \text { February } \\
1989\end{array}$ & $\begin{array}{l}\text { R.Sunardi (the Chief of } \\
\text { Coordination of Support } \\
\text { for the Development of } \\
\text { National } \\
\text { Stability/Bakorstanasda } \\
\text { for South Sumatera), }\end{array}$ \\
\hline Antara & $\begin{array}{l}\text { Arrested, Hordes of Mujahidin } \\
\text { Fisabilillah Command/People } \\
\text { who struggling in path of Allah } \\
\text { (Ditangkap, } \\
\text { Komandor Gerombolan } \\
\text { Fisabillillah). }\end{array}$ & 1 & $9_{1989}^{\text {February }}$ & $\begin{array}{l}\text { Try Sutrisno, the } \\
\text { Commander of } \\
\text { Indonesian Armed } \\
\text { Forces), Sunardi the } \\
\text { Chief of Coordination of } \\
\text { Support for the } \\
\text { Development of } \\
\text { National } \\
\text { Stability/Bakorstanasda } \\
\text { for South Sumatera), }\end{array}$ \\
\hline $\begin{array}{l}\text { Berita } \\
\text { Yudha }\end{array}$ & $\begin{array}{l}\text { Its successful attacking, the } \\
\text { Hordes of Mujahidin Fisabilillah } \\
\text { Command (Berhasil Ditumpas, } \\
\text { Gerombolan "Komando } \\
\text { Mujahidin Fisabilillah) }\end{array}$ & 1 & $\begin{array}{l}10 \text { February } \\
1989\end{array}$ & $\begin{array}{l}\text { R.Sunardi (the Chief of } \\
\text { Coordination of Support } \\
\text { for the Development of } \\
\text { National } \\
\text { Stability/Bakorstanasda } \\
\text { for South Sumatera), }\end{array}$ \\
\hline
\end{tabular}




\begin{tabular}{|c|c|c|c|c|}
\hline Mass Media & Title & Page & Datc & Source \\
\hline $\begin{array}{l}\text { Berilia } \\
\text { Yudhia }\end{array}$ & $\begin{array}{l}\text { Its successful attacking, the } \\
\text { Hordes of Mujahidin Fisabilillah } \\
\text { Comnnand (Berhasil Ditumpas, } \\
\text { Gerombolan "Komando } \\
\text { Mujahidin Fisabilillah) }\end{array}$ & 1 & $\begin{array}{l}10 \text { February } \\
1989\end{array}$ & $\begin{array}{l}\text { R.Sunardi (the Chiel of } \\
\text { Courdination of Support } \\
\text { for the Development of } \\
\text { National } \\
\text { Stability/Bakorstanasda } \\
\text { for South Sumatera), }\end{array}$ \\
\hline Jakarla Pust & 7 Moslem Radicals Die in Class & 1 & $\begin{array}{l}10 \text { February } \\
1989\end{array}$ & $\begin{array}{l}\text { R.Sunardi, (the Chiel of } \\
\text { Courdination of Support } \\
\text { for the Development of } \\
\text { National } \\
\text { Stability/Bakorstamasdat } \\
\text { for South Suntera) and } \\
\text { Try Sutrisno (the } \\
\text { Commander } \\
\text { Indonesian } \\
\text { Forces) Armed }\end{array}$ \\
\hline Kompas & $\begin{array}{l}\text { The Riot Case in Lampung: } \\
\text { Indonesian Armed Forces } \\
\text { succeed in controlling situation } \\
\text { (Kisus Kerusuhin di Lampung: } \\
\text { ABRI Berhasil Kendalikan } \\
\text { Situasi) }\end{array}$ & 1 & 10 February & $\begin{array}{l}\text { R. Sunardi (the Chief of } \\
\text { Coordination of Support } \\
\text { for the Development of } \\
\text { National } \\
\text { Stability/Bakorstamasda } \\
\text { for South Sumatera) }\end{array}$ \\
\hline Merdeka & $\begin{array}{l}\text { The Hordes of Mujahidin } \\
\text { arrested (Gerombolan Mujahidin } \\
\text { Ditangkap) }\end{array}$ & 1 & $\begin{array}{l}10 \text { February } \\
1989\end{array}$ & $\begin{array}{l}\text { R. Sunardi (the Chief of } \\
\text { Coordination of Support } \\
\text { for the Development of } \\
\text { National } \\
\text { Stability/Bakorstanasda } \\
\text { for South Sumatera) and } \\
\text { Tri Sutrisno }\end{array}$ \\
\hline Pelita & $\begin{array}{l}\text { Indonesian Armed Forces } \\
\text { succeed in breaking the Hordes, } \\
\text { using Religion as Mask ( } \Lambda \text { BRI } \\
\text { Berhasil Patahkan Gerombolan } \\
\text { Berkedok Agama) }\end{array}$ & 1 & $\begin{array}{l}10 \text { February } \\
1989\end{array}$ & $\begin{array}{l}\text { R. Sunardi (the Chief of } \\
\text { Coordination of Support } \\
\text { for the Development of } \\
\text { National } \\
\text { Stability/Bakorstanasda } \\
\text { for South Sumatera), }\end{array}$ \\
\hline Poskota & $\begin{array}{l}\text { - The Command of Mujahidin } \\
\text { Fisabilillah acted Subversive } \\
\text { Activity (Komando Mujahidin } \\
\text { Fisabillillah Lakukan Kegiatan } \\
\text { SubversiD. } \\
\text { - The United Development Party's } \\
\text { Statement on Mujahidin } \\
\text { Fisabililah (Pernyataan PPP } \\
\text { Tentang Mujahidin Fisabillilah) }\end{array}$ & 1 & $\begin{array}{l}11 \text { February } \\
1989\end{array}$ & $\begin{array}{l}\text { Sudomo, } \\
\text { Indonesian the } \\
\text { coordinator of politic } \\
\text { and defense, } \\
\text { Jailani Naro and } \\
\text { Mardinsyah, DPP, PPP. }\end{array}$ \\
\hline
\end{tabular}




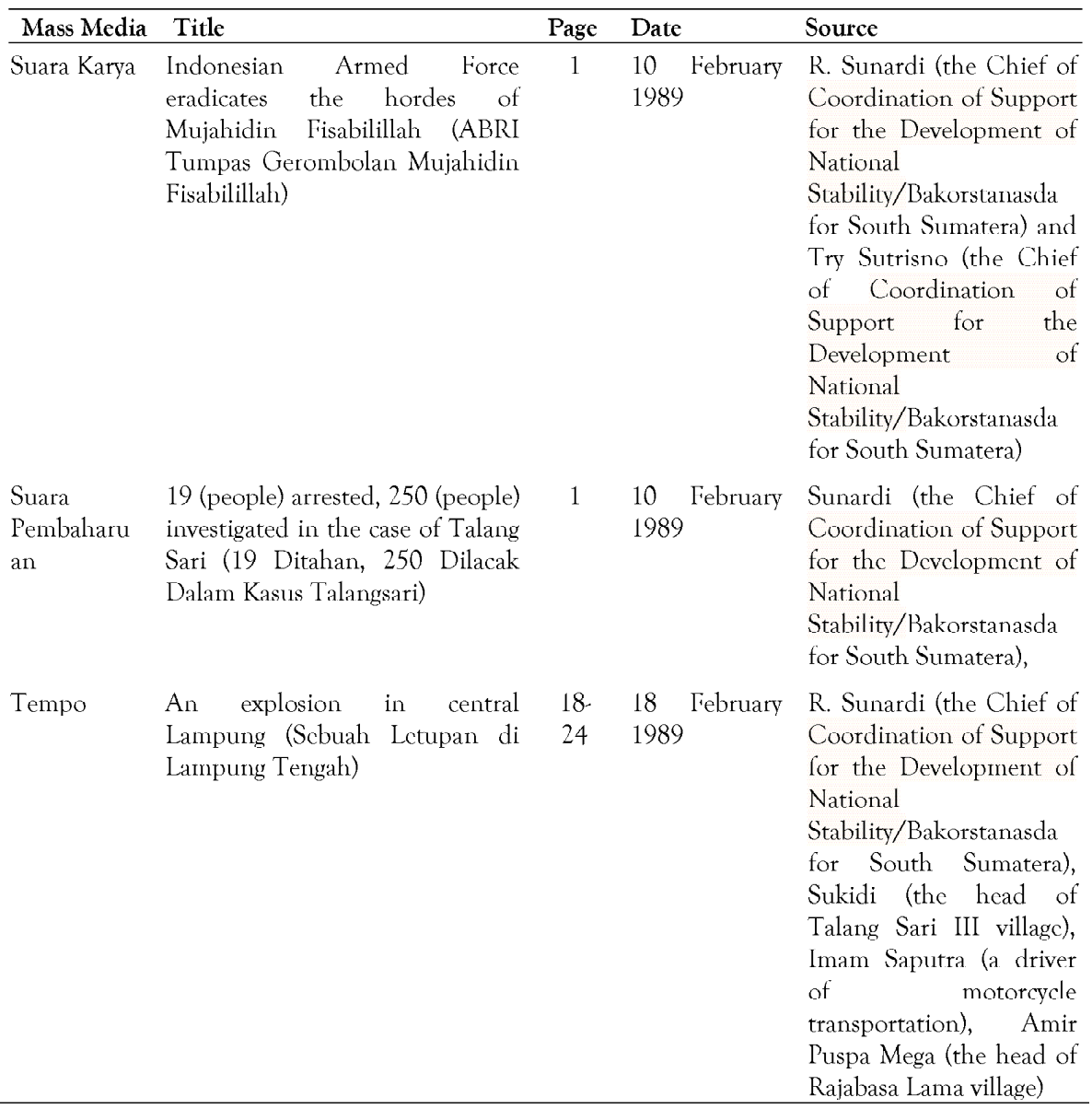

Not including Tempo, many mass media from the table cited the military as well as the government's sources in covering the Talang Sari. There were four persons, mainly Maj. Gen. R. Sunardi (the Chief of Coordination of Support for the Development of National Stability/Bakorstanasda for South Sumatera), Gen. Try Sutrisno (the Commander of Indonesian Armed Forces), and Sudomo (the Indonesian Ministry Coordinator of Politic and Defense). Among those persons' words, R Sunardi was the most one who talked it in detail and comprehensively, in which the amount of the victims was only 30 people. However, regarding the words' 
content, their saying in the Indonesian public was in the same line. There was explaining that the subject of violator was Komando Jihad Fisabilillah, and the aim of the movement was to destruct Indonesian nationality and its stability as a form of the subversive group who was anti-Pancasila as the sole of Indonesian state foundation.

The hordes that use religion as the mask was trying systematically to agitate people to undermine both nation and state through the actual speeches by saying, for instances, the government was unbeliever. They also prohibited going to Indonesian public school and becoming Indonesian government official as well as asking to fight against Indonesian Armed Forces and denying for paying the tax...The Hordes that called themselves as a command of Jihad Fisabilillah was subversive movement. Before growing largely and more dangerous, while the case was still beginning the level, they had to finish it immediately (Maj. General R. Sunardi, the Chief of Coordination of Support for the Development of National Stability, Pelita, 10 February 1989). ${ }^{15}$

However, compared to those mass media, Poskota was a little bit different by giving space for both Jailani Naro and Mardinsyah as the representative of the National Leadership Council of the United Development Party that well known as Islamic party in Indonesia. Instead of giv-

15 See, "Due to the event in Lampung at the first of this week, the Commander of Indonesian Armed Forces asserted that he just justified any acts firmly and wisely by security apparatuses regarding on every movement that could be disturbing (Indonesian) national stability and gnawing national development where they obviously as anti-Pancasila ideology and the 1945 constitution. 'I appeal for Indonesian to keep calm and to stay aware as well as to uphold national unity' (Gen. Try Sutrisno, the Commander of Indonesian Armed Forces, Suara Karya, 10 February 1989). "Beside of the latent danger of G30S/PKI such as a right extremist, left extremist, Sudomo reminded that the group of society who provoked liberal term and used the name of religion as a tool to achieve their goal was a threat for national stability that must be aware constantly.... His awareness of the movement that acted by the groups of society was either a thing-fetched or castle in the air" (Sudomo, the Indonesian Ministry Coordinator of Politic and Defense, Poskota, 11 February 1989). 
ing a different view about it, they supported the government opinion by reading an open statement that the tragedy was both disturbing national stability and destructing Pancasila. Because of this, every threat movement then must be eradicated. They also appealed all Indonesian, especially the party member to be aware of every issue that could be a trigger to destruct for Indonesian United and its national stability (Poskota, 11 February 1989). Despite what they said seemingly as same as the government's words that represented by three persons above, this statement could be seen as an indicator of an Islamic group that predominantly did not support it. Whereas, in 1978, the United Development Party as the one Islamic party hardly criticized the New Order's policy on implementing the doctrine of Pancasila as the sole of all Indonesian ideology through a training of P4 (upgrading course on the directives for the realization and implementation of Pancasila/Pedoman, Penghayatan, dan Pengamalan Pancasila) in the Associate Council Meeting of People's Consultative Assembly (Sidang Umum MPR). The form of these members of the United Development Party's resistance could be seen by their act of walk out in the midst of meeting. ${ }^{16}$

Unlike those mass media, Tempo, based on both library research and investigation report, tried to take a different view by covering it comprehensively. The aim of doing this was to provide "a reportage event honestly to be trusted by doing both check and balance as long as they can, so Indonesian would not be confused regarding on the hearsay" that was published in national newspaper. To take both sides in covering, Tempo then pointed their three journalists, mainly Agung Firmansyah, Gunung Sardjono, and Ahmadie Thaha to investigate it. As a result, they did not only get the tragedy chronologically but also made a map of the Talang

\footnotetext{
${ }^{16}$ Solahudin, NII Sampai JI: Salafy Jihadisme di Indonesia. Jakarta: Komunitas Bambu Solahudin, 2011, 165.
} 
Sari III village that consist of houses where many Warsidi's members were living. In addition, by taking interview with local people around and within the village (such as Sukidi, Imam Saputra, and Amir Puspa Mega), they knew at deeper the context of the Talang Sari village environment between residents and newcomers as well as the background of Warsidi's members that were coming from "Islamic militant people" whom intended to establish Islamic state in Indonesia (Tempo, 18 February 1989).

However, citing the government apparatuses as the essential information, this investigation report eventually tended to blame on Warsidi and his members of Islamic gathering activities. Tempo did not mention the members that were coming from many backgrounds. One of them were both ordinary and poor people who did not know what was Islamic ideology as well as they were an apolitical experience of being Islamists. The things that encouraged them to join the Islamic gathering were they wanted to learn Islamic religion and its values deeply in the midst of their activities as mostly farmers. Given this explanation, I realized, as they considered in introduction of editor letter on the first page of this magazine, doing an investigation report in the midst of authoritarian regime power was not easy while the military group, represented by Gen. R. Sunardi, Gen. Try Sutrisno, and Hendropriyono as the Commander of 043/Garuda Hitam Resort Military Command in Lampung tried to restrict information around it and to block its location from within the Talang Sari village residents and out of the local people as well as Indonesian generally. The main reason they did this way was in order to control a public discourse largely that they were not the enemy as mostly Indonesian Muslim perceived. The tragedy of Tanjung Priok that caused around hundreds of Muslim killed on September 12, 1984, was the real example how faces of the New Order regime as being anti-Islam. 
From 9-14 February 1989, the mass media called the tragedy on the five terms; 1) the event of Lampung, 2) the event of Talang Sari, 3) the event of Way Jepara, 4) the Command of the Mujahidin Fisabilillah (Muslims who struggle in path of Allah) members and 5) Warsidi's Security Disturbance Movement (GPK Warsidi). Despite all mass media had their term to call, but many of them used Mujahidin Fisabilillah as the first calling which was introduced by Gen. R. Sunardi. Meanwhile both Try Sutrisno, and Hendropriyono only strengthened their words. It seemed that the name of Mujahidin was taken by considering the international context of the Soviet War in Afghanistan (1979-1989) where the Afghanistan opposition groups well known as the Mujahidin, whom both provided assistance and supported aid by the US, fought against the government of the pro-Soviet Democratic Republic of Afghanistan (DRA). Nevertheless, instead of negative name in making an image of Warsidi and his members as an opponent group against the government, it was then worried to pay Indonesian Muslim attention to become more sympathy with his movement. Through the government apparatuses that represented by Brigadier Gen, Nurhadi, the Indonesian National Armed Force's the Head of Information Center; they replaced the name of Mujahidin to become GPK Warsidi. Instead of deserving to labeling as Mujahidin Fisabilillah, for him, it was correctly called as GPK Warsidi/ Anwar (the Security Disturbance Movement led by Anwar Warsidi), because their movement had caused of disadvantage for all Indonesian Muslim (Pelita, 16 February 1989). Though the name were coming from Warsidi and his members as the military thought, this replacing name was also asserted by Try Sutrisno to strengthen a character of Warsidi's movement. For him, they were inappropriate with both the proper name of Mujahidin Fisablillah itself and as part of the Islamic movement. 
According to the Commander of Indonesian Armed Forces (Try Sutrisno), the group name of Mujahidin Fisabilillah was found Warsidi himself as the Security Disturbance Movement. In fact, the name of Mujahidin Fisabilillah was a good reputation. The group of Warsidi used it intentionally to achieve both sympathy and support for Indonesian people (Suara Pembaharuan, 22 February 1989).

Of course, replacing the name was not only a way to delegitimize it as a movement that could be representing Islam in Indonesia as a form of protest but also showing the government's effort to influence Indonesian public discourse, primarily Muslim mass organizations. Doing both consolidation and coordination by coming to some mass Muslim organizations' meetings such as both Muhammadiyah and Nahdatul Ulama as well as inviting many Islamic religious leaders as well as Islamic teacher in Lampung after the tragedy by the military could be seen as one of those indicators. After doing this, the government began practicing stigma for the tragedy and Warsidi's members in proposing negative issues, such as a right extremist, communist (PKI), and GPK that not recognize Indonesian state and asking their members to not paying taxes and disobedient for Pancasila as the sole of Indonesian ideology. Indeed, they also perceived as a movement who wanted either to do or not to do. For instance, they perceived 1) to do free sex relying on their doctrine, 'my joy is also yours' (nikmatku adalah nikmatmu), 2) to not wearing trousers for man and bra for a woman, 3) and to practice a deviance stream (aliran sesat) of lelampah. ${ }^{17}$

Those conditions were successful in shaping mostly Indonesian Muslim's view on the tragedy, where the three biggest mass Muslim orga-

\footnotetext{
${ }^{17}$ Some of indicators of the Lelampah stream were their members compulsory; 1) to pray five times at the land without using a carpet, 2) to prohibit finding out riches, 3) and to not allowed for praying together an out of their members, although they were as the same Muslims. Abdul Syukur, Gerakan Usroh Di Indonesia: Peristiwa Lampung 1989. 2003,...1.
} 
Indonesian Muslim killings: revisiting the forgotten Talang Sari tragedy (1989)... (Wahyudi Akmaliah)

nizations as the representative of Indonesia Muslims, such as Muhammadiyah, Nahdatul Ulama, and Indonesian Ulama Council (MUI) were eventually not only refusing it as a part of Islam but also suspecting it as the other of Islam that the so called as the splinter group of Muslim (aliran sesat) who were out from Islam. Besides those factors, there are two reasons why they were relatively objection with it. Firstly, it was more political orientation where both previously agreed with Pancasila as the sole of all Indonesian ideology. Secondly, compared to both who had Islamic school of thought relying on the four imam as the primary sources in the common of Islamic Law (Hanafi, Maliki, Syafi' i, and Hambali) in their practical religious orientation, the Talang Sari was only based on the imam Ja'fari as their school of thought in Islamic jurisprudence (Syukur, 2003: 147). Nonetheless, there is the fact that was some of the members originally from Muhammadiyah, such as Zamzuri, Azwar Kaili, Amir, and Suparmo. ${ }^{18}$

\section{Islah and cultural impunity}

\section{The emergence of islah}

In regard of change period (1998-2000), although it was one of the cases could be revealed, there was a movement coming from AM

\footnotetext{
${ }^{18}$ Meanwhile, this producing stigma could be seen through the victims and their families' experiences during the Suharto presidency while they perceived as PKI (Indonesian Communist Party), a group of rebellion, a splinter group of Muslim and the other stereotypes in discriminating them. The voice of Ibu $(\mathrm{Mdm})$ Widaningsih is as one of the victims' voices that describes those conditions. "As a witness, I was not only seeing and listening but also facing the terrible of Talang Sari tragedy. There were more than two thousand victims killed and many of them who were living lost their valuable things had been marginalized by people around them. They also stigmatized as an insurgent, communist (PKI), and as part of deviate group. Because of this, I realize that the tragedy happened and, on the other hand, Indonesia is a state of the law. I hope it could be revealed through a rule of law with the fairest way for perpetrators, whoever they are and victims and its families who have been still living on the other hand" (Widaningsih. 23 June 2007/Berita Acara Pemeriksaan/Nomor: 47/TPPT/VI/2007/Komnas Ham)
} 
Hendpriyono as a 'perpetrator' to not uncover it by offering at (reconciliation in Islamic term) on around of the one month after Suharto stepped down. There is one reason why he offered it vastly than most academician and human rights activists thought. When Habibie, the vice of Indonesian, became Suharto's successor as a president, this condition gave a chance for Hendropriyono to replace Wiranto as Commander in Chief of the Indonesian Armed Forces (ABRI). For human rights activists, Wiranto himself was a mastermind behind some of the blood tragedies, such as the disappeared activists (1997), the riot of May (1998), the event of Semanggi (1998), the killing of dukun santet/Shaman (1997), and the conflict among Muslim and Christian in Ambon (1999). However, because of some reasons, Habibie canceled to hire him and then gave a position to to as the Ministry of Transmigration and Forest Squatter Resettlement. Despite he got a good position, it did not mean he was clear from Suharto legacies of violence in the midst of transition era as the juncture from an authoritarian regime to democracy system. He was still a problem with human rights past violation, mainly the Talang Sari. Doing the act of islah as one of his initiatives to erase his responsibility eventually was a rational option. ${ }^{19}$

Although Kontras's report saying that peace agreement in the name of Islah had been done for four times (2009), after collecting documentation from mass media, I just can say only twice of the Islah agreement between perpetrator and victims did. First is peace agreement in 1998 represented by some of the victims (such as Nurhidayat, Sudarsono, Fauzi, Maulana, and Ahmad Yani Wahid) and AM Hendropriyono as a person who responsible for the Talang Sari tragedy. Through this agreement, the victims got some compensation. Second is a peace agreement in 1999 as a form of negotiation between Hendpropriyono and the victims who

\footnotetext{
19 Wahyudi Akmaliah, Menggadaikan Islah...,116-117.
} 
become political prisoners during the Suharto presidency. The result of it was there were thirteen from fourteen of the victims who previously become political prisoners had been released from the prison based on the presidential decree remission, no. 101/G/1998. Because of this, the case of Talang Sari tragedy had been closed, and those of the victims, as well as Hendropriyono, then declared the Islah National Movement (Gerakan Islah Nasional/GIN) as a nation moral movement. ${ }^{20}$ The idea of Islah movement then introduced by those to other victims and their families following the two kinds of compensation they would get, the mainly amount of money as a capital for their small business and a job they would get a contract labor in the farm of shrimps and plantation of oil palm as promised by Hendropriyono. Hendro also built a mosque within the village of Talang Sari. However, many victims in the midst of Islah process felt they were betrayed on the agreement. Those of the 28 victims then gave a public statement in a press conference that they were out of islah agreement on September 6, 2001. Accompanied by KontraS, they also insisted the Indonesian government reveal it. Meanwhile, the rest of them still want to forget their past violation by hindering the other victims whom wanted to demand justice in coming to the government and its institutions and, on the other hand, they often socialize that the case has been closed by promoting GIN.

In regard to the betrayal agreement, it seemingly was not coming from Hendropiyono himself but from the elite of victims that always take a position as a medium between Hendro and all of the Talang Sari victims. As the person who were represented and believed by all of the victims, they used their position to take advantage, mostly to get money. ${ }^{21}$ In

${ }^{20}$ Irfan S Awwas, Trauma Lampung Berdarah: Di balik Manuver Hendropriyono. Yogyakarta: Wihdah Press, 2000. Kompas, 18 Januari 1999. Kontras, 2006. Wahyudi, 2009).

${ }^{21}$ Sugeng Yulianto as one of the victims' voices below can explain it very well, "Not too long after release, Sudarno invited me by phone to celebrate syukuran (an expression of 
regard of the elite of the victims as negotiator to get advantage, it also happens in the case of Tanjung Priok. In the name of Tim Tujuh (a group of seven) as thought the victims' representation, they exploited the victims' identities to reconcile with perpetrators in the islah way while the Tanjung Priok court Ad Hoc definitely will be holding on one month later. Ironically, unlike the case of Talang Sari, this islah initiative was not coming from perpetrators but from the member of the victims as the so-called of Tim Tujuh. Instead of seeing a victim as apolitical person who are poor idea and a weak condition so therefore people should help them to get justice, in this context, the victim also has an autonomy body to negotiate their identity with perpetrators in order to achieve a goal what they want. On other hand, they understand very well that perpetrators need their false narrative to help them from their act of violence in the past. Here, there were many things they got by doing this way in the case of Tanjung Priok. They were not only got much money from

gratitude to God) together with the former prisoners of Nusakambangan Penitentiary at Jakarta Jakarta. Surprisingly, he brought me and other friends to the Mosque of Al Muhajirin at Department of Transmigration and Forest Squatter Resettlement in order to meet Hendropriyono as the Minister Transmigration and Forest Squatter Resettlement. The day was Friday when we did Jumat pray together. After praying, I met him. When he hugged and kissed me on the left and the right cheek, he said that "It is true that you are sentenced less than ten years. Now we forgive each other and I will pay more an attention on the former prisoners' prosperity". It seemed that his promise only for certain people who closed to him. There was ever that Sutan Sharir from Hendpriyono's a lawyer, sent me money through my child. Another day, Maulana Latif from Cilengsi, West Java, come to me to look around a condition of my house. Maulana informed me about the investor. His name is Firman who works as a butcher of cattle at Pasar Klender. He is really interested in growing vastly of cattle. Maulana then gave me money of the twelve thousand million rupiah (1200 USD) where those money he got from Firman. I then used it for buying six of cow. I just realized that the money definitely was from Hendpriyono. I got this information while Hendropriyono invited me together with Maulana to his house in Cibubur, West Java. Hendro surprised when he knew that only the six cows I raised because he already gave fifty million rupiah (5000 USD) to Maulana. Maulana just said to us that all of the rest money had been given to all of the victims. Sugeng Yulianto. 21 Juni 2007/Berita Acara Pemeriksaan/ Nomor: 26/TPPT/VI/2007/Komnas HAM 
perpetrators but also got valuable things to make their life more survival such as motorcycle and network to get job access. ${ }^{22}$

\section{Islah as a mode of reconciliation}

The questions that remain on Islah as Islamic term for reconciliation and peace agreement in Islamic perspective in the case of Talang Sari are whether is it used to strengthen an argument of reconciliation following the sources of Islam (Al-Quran and Sunnah)? or only as a pretext to forget past violation without revealing the truth in court? As long as I trace, there is no document and note regarding the Islah agreement. Indeed, there is no explanation why they use the name of Islah. The information I can trace on the term of Islah in the case of Talang Sari is only from the book of Geger Talang Sari: Serpihan Gerakan Darul Islam, written by Widjiono Wasis. Instead of explaining it in the proper way, the author accuses all of the victims as those people who want to establish Islamic country by joining the group of Darul Islam. The book then is more kind of propaganda to blame all of the victims rather than to give an explanation proportionally why the tragedy happened and what the main reason Islah has emerged in post-Suharto regime vastly is.

In this book, Wasis talks Islah within the two chapters, mainly Islah sebagai Alternatif Penyelesaian (Islah as an alternative Solution, 218-225) and Respon Seputar Islah (a respond around islah, 226-239). In the chapter, he describes it in two explanations. First is about the term Islah itself. For him, the word of Islah originally comes from the source of Al-Quran. Islah means either peace or improvement. Ordering for Islah, it covers all of the improvement that related and consists of theological (tashlihulaqidah), worship (tashlihul ibadah), moral (tashlihul akhlak), economic (tashlihul iqtishodiyah), and political system (tashlihul siyasah). All of those

22 Wahyudi Akmaliah, Menggadaikan Islah ...,143-147. 
improvements, Wasis asserts, is focused more on increasing the commitment to improve that already right. However, ordering Islah, in particular, is more on improving things that are already damaged, especially on improving social relation (tashilul mua'malah) by ending conflict, tension, blasphemy as well as enmity. Second is practiced islah in the context of Muhammad prophet era as a case study. For example, under the leadership of Khalid bin Walid, there were troops in feeling angry who killed the tribe of Banu Jadhimah, whereas the battle among them was already over. Due this critical situation, Muhammad then decided to point Ali Bin Abi Thalib to investigate it by saying, "go directly to those people, do examining in detail, and act stopping to end the bad habit they have." He also asked Ali to bring money to exchange for the spilled blood and the loss of property in the battle.

At the first explanation, instead of explaining profoundly, Wasis just describes it partly and examines it in literally. For him, the significant of Islah is to improve social relation among people that are previously damaged due to conflict and tension. Does he not examine what is the meaning of Islah in the context of Islamic jurisprudence while killing is happening? How the mechanism of forgiveness in the midst of public court to achieve justice? What is both reparation and compensation that the victims will get? In the second explanation, he also does not explore it deeply regarding the right of the victims they have to get it and what a lesson learned for Indonesian public so the tragedy will be not happening again in the future. By proposing the picture of Muhammad's prophet era, he seemingly assumes that the killing in the Talang Sari is just both conflict and tension as a simple business without causing victims and dead people. In fact, regarding killing, there is a discussion of the qisos (killing) concept that consist of four level deal with the behind reason of people why they kill and its consequences in Islamic jurisprudence. Therefore, 
the term of Islah and how it is practiced in the case of Talang Sari are a pretext to forget the past violation rather than proposing peace agreement in Islamic perspective as a proper way to end the conflict and to cut off vengeance.

To strengthen Islah as a mode of reconciliation that could be a pretext as explained above, I argue that there are three impacts that could be seen clearly. In the first point, in the name of Islah, the victims' group who were joining at GIN tried to block every effort for both the $\mathrm{Na}$ tional Commission on Human Rights in tandem with KontraS in order to reveal the truth of the tragedy by establishing the Commission of Inquiry on Human Rights Violation (KPP HAM). Also, they often said in the public that the case is already closed, and they did not want to recall their bitter past by revealing it due to both some of them and perpetrators had made an agreement in the mode of Islah. In the second point, they terrorized the other victims. The victims group who were pros of Islah often terrorizes the other whom as anti of Islah in two ways; 1) they were not only blocking the other victims who wanted to cross Island at the harbor of Bakeuni-Merak but also giving a threat in order to kill them if they really wanted to go to Jakarta, 2) by using local apparatuses, they also threaten for those victims will be losing their family member if they still insisted on seeking justice. In the third point is an act of forgetting. A local government in the village of Talang Sari often visited the victims by face to face in their houses. Instead of talking about the case condition, they asked them to forget the past violation by giving them money around Rp.5000 (50 Cent USD)-10.000 (1 USD) as a form of hush money to keep their memory silently. Also, there were Hendro's people as his representation person who were holding Islamic gathering regularly by inviting the victims and individuals around Talang Sari. This Islamic gathering is not on only used to teach Islamic values but also as 
space to deliver a doctrine by a preacher so the victims would not demand their justice in the court. ${ }^{23}$

It is evident that Islah has been one of many factors among the barriers to obtain justice. Instead of structural level in the government's institutional justices as well as the judicial proceedings to process human rights court, I argue islah is one of the negative contributions that has strengthened cultural impunity, so human rights past violation are quite difficult to reveal in the post-authoritarian regime, especially in the case of Talang Sari. Through cultural negotiation in the name of islah as if they use Islamic term for making peace and reconciliation, both the victims and perpetrators try to false their memory on what was happening in the past. Although there are some of the victims, insist on pursuing their struggle to get justice, this fragmented memory (between remembering and forgetting) among them caused a lot of difficulties to prove it legally up to now. On another hand, one of the cases that are using islah as the pretext to forget the past that then made the victims group had divided into the two memories is the Tanjung Priok case. Because of this islah agreement, the Human Rights Ad Hoc of Tanjung Court then has been released perpetrators from their responsibility in 2007 (Akmaliah, 2009). I believe if there is no solution deal with the problem of islah in Talang Sari, it will be the same condition as the Tanjung Priok though the case still unsolved currently.

\section{Concluding remarks}

Unlike the Tanjung Priok, the Talang Sari is relatively obscure for many social scientists to conduct research, due to the location that is away from Jakarta to the capital city. In addition, the influence of the New Order

${ }^{23}$ KontraS, Peristiwa Talang Sari 1989: Sebuah Kisah Tragis Yang Hendak Dilupakan, Jakarta: Kontras, 2006, 9-10. 
regime in dominating public discourse through a centralized mass media nationally to cite the information source from the government and the background of the biggest mass Muslim organizations (NU and Muhammadiyah) that already agreed to implement Pancasila as the sole of their ideology in 1980s had strengthened Warsidi and his followers as the deviant group of Islam, well known as GPK.

In fact, there are three factors why it happened. First, it is the national level where the case is like the second moments while Suharto perceived Islam as a threat by controlling and forcing all political parties. In addition, it is all mass organizations including Islamic organizations to adopt the state of ideology as the sole of their ideological basis as well as prohibiting every symbol that showing Islam in the public sphere. Second, there were people who migrated from Java to the village of Rajabasa in South Lampung as part of their strategy to avoid from the operation target during 1985-1986 which acted by Harsudiono Hartas, the General Major of the Diponegoro Territorial Military Commander, regarding their activity as the Islamist whom joint the Usrah Movement, led by Abdullah Sungkar in Solo, Central Java. Those people then met Warsidi and his followers to make Islamic village. Due to their influence, Warsidi's Islamic gathering was hardest and radical dealt with the local government and its policy. Third is the series of unresolved local conflict between Warsidi's Islamic gatherings (including the members of Usroh movement) versus local apparatuses particularly the military group from the Indonesian Armed Force. Undeniably, Warsidi's attitude in establishing a relationship with the local devices was worst, especially Warsidi and his members' stubborn who did not want to come to the call letter that had been invited to three times. Although, the act of killing in attacking them in the early morning on February 7, 1989, is abuses of their power as the government apparatuses that committed human rights violations. 
In the post of Suharto regime, there is hope for the victims of violations to break their silences including the victims of Talang Sari tragedy. This condition, cited the report of both ICTJ and KontraS (2011), is as the momentous change (1998-2000) under both the Habibie and Abdurahman Wahid Presidency, who have had clear of political commitment to transitional justice. The momentum then was stolen by Hendropriyono to make a clear of his name while he took a position as the Minister of Transmigration and Forest Squatter Resettlement by offering islah to the most of the victims and their families in 1999 and 2000. Sadly, the Islah agreement becomes a fundamental factor as the barrier to reveal it due to the victims' option; mostly they are pros of Islah, who want to forget the past of their bitter memories by pawning their identities of the victim-ness to get the economic benefit. Though there are many problems as said before why those cases of human rights violations difficult to bring to court, the islah agreement becomes a negative contribution why cultural impunity steeply embedded to bring justice for the victims, mostly in the case of Talang Sari and Tanjung Priok.

\section{Bibliography}

Akmaliah, Wahyudi. 2009. Menggadaikan Islah: Politisasi Islah di Kalangan Korban Priok (1984). Yogyakarta: Syarikat Indonesia.

Akmaliah, Wahyudi. 2010. Dari Penjara Ke Penjara: Narasi Personal Kehidupan Azwar Kaili, Korban Peristiwa Talang Sari, 1989. Naskah Tidak Diterbitkan.

Awwas, Irfan S. 2000. Trauma Lampung Berdarah: Di balik Manuver Hendropriyono. Yogyakarta: Wihdah Press.

Burhani, Ahmad Najib. 2014. "The Reformasi '98 and the Arab Spring: A Comparative Study of Popular Uprisings in Indonesia and Tunisia", Asian Politics \& Policy, Volume 6, Number 2 (Pp 199-215).

Effendi, Bahtiar. 1998. Islam dan Negara:Transformasi Pemikiran dan Praktik Politik Islam di Indonesia. Jakarta: Paramadina.

Fadilasari. 2007. Talang Sari 1989: Kesaksian Korban Pelanggaran HAM Peristiwa Lampung. Jakarta: Lembaga Studi Pers dan Pembangunan (LSPP) 
Heffner, Robert. 2000. Civil Islam: Muslims and Democratization in Indonesia.

Princeton, NJ: Princeton University Press.

ICTJ (International Center for Transitional Justice) \& KontraS. 2011. Derailed: Transitional Justice in Indonesia since the Fall of Soeharto, Jakarta: ICTJ. KontraS. 2006. Peristiwa Talang Sari 1989: Sebuah Kisah Tragis Yang Hendak Dilupakan, Jakarta: Kontras.

Kontras. 2009. Kronik Perjalanan Kasus Talang Sari. Jakarta: Kontras.

Solahudin. 2011. NII Sampai JI: Salafy Jihadisme di Indonesia. Jakarta: Komunitas Bambu.

Sugeng Yulianto. 21 Juni 2007/Berita Acara Pemeriksaan/Nomor: 26/TPPT/ VI/2007/KOMNAS HAM.

Syukur, Abdul. 2001. Gerakan Usroh di Indonesia: Kasus Peristiwa Lampung 1989,

Tesis, Program Studi Ilmu Sejarah, Bidang Ilmu Pengetahuan Budaya, Program Pascasarjana Sastra, Universitas Indonesia.

Syukur, Abdul. 2003. Gerakan Usroh Di Indonesia: Peristiwa Lampung 1989. Yogyakarta: Ombak.

Wasis, Widjiono. 2001. Geger Talang Sari: Serpihan Gerakan Darul Islam. Jakarta: Balai Pustaka.

Widaningsih. 23 June 2007Berita Acara Pemeriksaan/Nomor: 47/TPPT/VI/ 2007/KOMNAS HAM.

Wieringa, Saskia Eleonora. 1999. Penghancuran Gerakan Perempuan di Indonesia. Jakarta: Garba Budaya

\section{Internet}

Akmaliah, Wahyudi. 2013. "Ingatan yang Diabaikan: Islam, Kekerasan Masa Lalu, dan Aspirasi Politik Pasca Orde Baru”, Pusat Penelitian Politik, LIPI, accessed from www.politik.lipi.go.id on 5 September 2014.

ElSAM. 2012. "Siaran Pers 23 Tahun Tragedi Talangsari: Ketika Negara Menolak Keadilan Korban", accessed from http://www.elsam.or.id/?id=1769\& lang $=$ en\&act $=$ view\& cat $=\mathrm{c} / 302$ on 17 June 2013.

\section{Newspapers}

Angkatan Bersenjata. 1989. "Polwil Lampung Tumpas Gerombolan Pengacau Keamanan di Talang Sari", 10 Februari.

Antara. 1989. "Ditangkap, Gerombolan Komando Mujahidin Fisabillillah", 9 Februari.

Berita Yudha. 1989. "Berhasil Ditumpas, Gerombolan "Komando Mujahidin Fisabilillah", 10 Februari.

Jakarta Post. 1989. "7 Moslem Radicals Die in Class", 10 February. 
IJIMS, Indonesian Journal of Islam and Muslim Societies, Volume 6, Number 1, June 2016: 1-34

Kompas. 1989. "Kasus Kerusuhan di Lampung: ABRI Berhasil Kendalikan Situasi”, 10 Februari.

Merdeka. 1989. "Gerombolan Mujahidin Ditangkap", 10 februari.

Pelita. 1989. ABRI Berhasil Patahkan Gerombolan Berkedok Agama, 10 Februari.

Poskota. 1989. "Komando Mujahidin Fisabillillah Lakukan Kegiatan Subversif", 11 Februari 1989.

Poskota. 1989. "Pernyataan PPP Tentang Mujahidin Fisabillilah”, 11 Februari 1989.

Suara Karya. 1989. "ABRI Tumpas Gerombolan Mujahidin Fisabilillah”, 10 Februari 1989.

Suara Pembaharuan. 1989. "19 Ditahan, 250 Dilacak Dalam Kasus Talangsari", 10 Februari 1989

Suara Pembaharuan. 1989. "Pangab: Peristiwa Lampung Lokal", 22 Februari 1989.

Tempo. 1989. "Sebuah Letupan di Lampung Tengah", 10 Februari 1989. 